\title{
Federalism and the Spanish First Democratic Republic, 1873-1874
}

\author{
Marta Postigo
}

Department of Philosophy, University of Málaga, Spain

Copyright $\bigcirc 2017$ by authors, all rights reserved. Authors agree that this article remains permanently open access under the terms of the Creative Commons Attribution License 4.0 International License

\begin{abstract}
Federal theory is experiencing new momentum in connection with contemporary political challenges such as the crisis of the nation-state and ethnic and cultural minorities that claim recognition and political autonomy. The present article presents a critical discussion on the principles that were enshrined in the Project of a Federal Constitution of the Spanish Republic of 1873 and the events that led to the first Democratic Republic in Spain, in order to highlight some basic tenets of federalism. The article is divided into four parts. Firstly, a general introduction to the paper is provided. The second part offers some methodological clarifications with regard to federal studies. Thirdly, the discussion takes place in two separate sections: the first one presents the events that led the proclamation of the first Democratic Republic in Spain in 1873; the second delivers a critical analysis of the federal principles that were enshrined in the Project of a Federal Constitution of the Spanish Republic of 1873. Finally, to conclude, two different principles are contrasted in relation to contemporary debates that arise in connection with the European Union and multicultural states: the principle of citizenship and the principle of cultural communities.
\end{abstract}

Keywords Citizenship, EU, Federalism, First Democratic Republic of Spain, Nationalism

\section{Introduction: New Momentum for Federalism?}

Federalism is a key concept of modern political thought ${ }^{1}$. The conceptualization and study of modern states cannot be fully addressed without federal ideas and arrangements ${ }^{2}$. Yet,

1 Daniel J. Elazar [18] has highlighted the existence of theological expressions of federalism and covenant principles (foedus) in ancient Israel, the Middle Ages and the Bible. However, the secular political meaning and use of federal ideas and theories arise in connection with the modern state and modern political thought.

2 Common examples are the United States of America (US) and the Swiss the era that witnessed the emergence and consolidation of the modern state is giving way to a postmodern epoch in which transnational flows of goods, persons and information are transforming former political boundaries and allegiances.

In our interconnected world, peoples and states are compelled to interact and cooperate in order to ensure their economic prosperity and security [2, 3, 24, 28]. With the help of communication technologies and the Internet, civic networks and engagements are able to flourish beyond local and national borders [9]. As a result, basic democratic concepts, institutions and political allegiances must be reappraised to adapt to the postmodern constellation ${ }^{3}$.

It is in this scenario that federal studies and ideas have reemerged [65]. Two main trends should be underlined. On the one hand, since World War II, European federalism has gained momentum within the debates on state integration and the creation of the EU $[48,50,54]^{4}$. On the other hand,

confederation, as well as The Federalists papers published in the US between 1787 and 1788 [25]. Federal ideas and principles have played a central role in modern and contemporary thought from Althusius [18,29] to classical nineteenth-century federalist thinkers such as the French Pierre-Joseph Proudhon (1863) [51] and the Spanish politician Francesc Pi i Margall's (1876) [46,47]. During the Enlightenment period, federal ideas were closely linked to cosmopolitan values and the law of peoples, for example, through Immanuel Kant's works $[36,54)$. Regarding federal ideas in John Stuart Mill's and Alexis de Tocqueville's political thought see Jewkes [30]. For a conceptual-historical outlook of the conceptual and rhetorical uses of federalism in nineteenth-century Spain see Ayzagar and Capellán de Miguel [1].

3 With regard to the post-national constellation see Habermas [24]. The "Second Age of Modernity" and European cosmopolitanism have been conceptualized by Beck [4] and Beck and Grande [5,6]. A political analysis of democratization in the global order can be found in Held [26] and Held and McGrew [27]. For the debates on supranational democracy that arise in connection with the EU see Postigo [49].

4 In the midst of World War II, the Ventotene Manifesto for a Free and United Europe, drafted by Altiero Spinelli and Ernesto Rossi while they were prisoners on the island of Ventotene, became a cornerstone of the Movimento Federalista Europeo. The Shuman Declaration, which gave rise to the European Coal and Steal Community (ECSC) in 1950, also contained explicit federal commitments with regard to the future integration of Western European states: [https://europa.eu/european-union/about-eu/symbols/europe-day/schumandeclaration en] [44]. Certainly, it is a matter of debate whether the federal terminology is useful and suitable to define a postmodern polity such as the EU. Contemporary scholarly literature is still deeply divided on the topic. For different critical perspectives on the issue see some references Beck and Grande [6]; Burgess [7]; Castaldi [8]; Dosenrode [16]; Schmitter [58,59]; Postigo [48,50]. 
federalism has acquired new significance in connection with demands for recognition of cultural minorities [30, 34, 65] and secessionist movements, such as the Catalans' and Basques' in contemporary Spain $[23,35,55]$. While the first one is a clear example of the postmodern dynamic that brings peoples and states closer towards new forms of political cooperation and integration, the latter reflects the main paradox of globalization, that is: as the world gets increasingly interconnected, ethnic claims reemerge dividing citizens along national and ethnic lines.

Allegedly, federalism becomes a useful tool to address both phenomena, that is, interstate integration, as in the case of the EU, and demands for political autonomy and cultural recognition of ethnic and national minorities. Yet, it is difficult to envisage what of the two tendencies, the centripetal or the centrifugal, is going to be decisive in twenty-first century federalism. It seems, though, that federal theory and solutions are likely to stay and play an important role in postmodern political theory.

This paper offers a discussion on the federal principles that were enshrined in the Spanish Project of a Federal Constitution of 1873 and the experience of the first Federal Democratic Republic of Spain (1873-1874). This historical example reveals a gap between the theoretical ideals and goals of the Spanish nineteenth-century federalists, and the concrete political circumstances that prevented the success of the republican regime.

In order to carry out this purpose, the following section will present some methodological clarifications that arise when dealing with controversial and contingent political concepts such as federalism ${ }^{5}$. To continue with the discussion, in section three, the historical backgrounds and events that led to the First Federal Democratic Republic of Spain in 1873 and the main principles that were enshrined in the Federal Constitutional Project will be critically addressed and discussed. Finally, a reflection on the value and suitability of federal principles to deal with twenty-first century political issues, such as the European integration process, will be provided in the concluding remarks.

\section{Methodological Issues}

Federal studies testify to the interdisciplinary and multidisciplinary dimensions of contemporary scholarly research. In fact, federal literature covers studies of comparative federal systems, constitutional and legal approaches and theoretical discussions within the field of political and moral philosophy bringing together disciplines from the social sciences and humanities ${ }^{6}$ However, there

5 According to Elazar [18], federalism, as other basic political concepts, such as democracy, republicanism and liberalism, should be viewed as a "classic value concept", insofar as it "does not have a once-and-for-all-time precise definition in the usual scientific sense, although it can be and is defined operationally in well-accepted ways".

6 For instance, see Publius. The Journal of Federalism, a leading journal of federal studies. The Journal was launched by the federalist scholar Daniel J. seems to be a gap between strictly empirical comparative analysis of federal systems and decontextualized normative approaches to federalism, what could be overcome by having into account historical contexts and conceptual changes ${ }^{7}$

This paper attempts at filling in this historical vacuum by discussing the experience that took place in Spain during the first Federal Republic of 1873 -1874. The Spanish example, which has not been thoroughly discussed in classical federal works [18], provides a rather pessimistic illustration of federal ideals and aspirations, highlighting some of its paradoxes and failures. Although these pages deal with some theoretical controversies, what the Spanish historical example can bring to normative theory is a matter that will remain open to debate.

\section{Discussion}

\subsection{The Political Circumstances: Spanish Federal Republicanism and the Democratic Federal Republic of 1873-1874.}

In Spain, federalism gained momentum at the end of the nineteenth century when the first Democratic Republic was proclaimed in 1873 . The republican regime had a very short life. It lasted just eleven months, amid strong political struggles. This brevity was due to the political instability of the country -that included civil wars (Carlist uprising) ${ }^{8}$, military plots, economic crisis and cantonal revolts ${ }^{9}-$, as well as the internal divisions between centralists (Unitarians) and federalist republicans.

In spite of such instability, the republican period gives insight into the political and moral commitments of Spanish nineteenth-century federalists. The leading intellectual and political figure of federalism in Spain at that time, Francesc Pi y Margall [48, 49], believed that the federal democratic

Elazar and is currently edited by John Dinan and the Temple University's Center for the Study of Federalism, Oxford University Press. The official website: https://academic.oup.com/publius. For an historical outlook of comparative studies of federalism see Watts [66]

7 The normative approach I am referring to can, for example, be found in Weinstock [67] and Jewkes [30]. With regard to the importance of taking into account historical conceptual changes and rhetorical uses of political and social concepts see Koselleck [31-33], Palonen [41,43], Palonen, Rosales and Pulkkinen [42], Rosales and Toscano [56]; Rosales [57]; Skinner [60]; López and Rosales [37].

8 The Carlist Wars were a series of civil wars that took place in Spain after the death of Kin Ferdinand VII in 1833, lasting until the end of the nineteenth century. They were held between two main political sectors: on the one hand, traditionalist monarchical supporters of Carlos V, and, on the other hand, liberals and republicans that supported the Regency of María Christina and her daughter, Isabel II, when the latter became of age to reign. The wars broke out in several episodes: 1833-1840, 1846-1849, and 1872-1876. In fact, they had a strong regional dimension since, through the succession disputes, the Carlists aimed at preserving traditional legal and territorial prerogatives (fueros) that the liberals called into question on behalf of the principle of equal citizenship and constitutional reforms.

9 Starting in Cartagena on July 1873, the cantonal rebellions were a series of cantonalists uprisings that spread out, during the first Spanish Republic, through several regions such as Valencia and Andalusia, but also in provinces of Extremadura, Salamanca and Ávila, on behalf of autonomous cantons (towns or cities) and the creation of a Spanish federation made of independent units. 
republic would bring the solution to the Spanish evils. The republican federation would allegedly achieve two main political goals: on the hand, the modernization of Spain according to democratic and liberal values, and, on the other hand, the arrangement of the territorial and administrative decentralization of the nation. However, in practice, the political reality of the country, marked by deep internal divisions and radicalism, prevented the necessary national unity and consensus for the republican regime to prosper.

If the political circumstances had been different, would federalism have succeeded in that country? Was the failure of the federal republic caused by inappropriate ideas or adverse political circumstances?

Before dealing with these controversial questions, it is important to be acquainted with the political events that led to the republican regime. In fact, the Republican Democratic Federal Party acceded to power as a consequence of the September Revolution of 1868 , which gave rise to the so-called "Revolutionary Six Years" (1868-1874). That period hosted two political regimes: A Constitutional Parliamentary Monarchy, from June 1869 to February 1873, and the first Republic, from February 1873 to January 1874. The Diaries of the Parliamentary Sessions of that time, which can be accessed through the Congress's webpage, offer testimonies that reflect the unstable and unforeseen circumstances that led to the republican regime in $1873^{10}$.

After the September Revolution, the Cortes decided to reinstate the Monarchy under a new dynasty. As a result, Isabel II was deposed and King Amadeo of Savoy was elected monarch by the Cortes in 1870 . However, his election coincided with the assassination of his main political supporter, General Prim. This left the King almost without political support and under extremely unstable circumstances, which included several republican conspiracies, revolutionary movements in Cuba, deep internal divisions within the progressive party, Carlist uprisings, and assassination attempts, all which led to his abdication on 11 February 1873.

After the King's abdication, a National Assembly ${ }^{11}$ was declared and the first Spanish Republic was proclaimed by 258 nominal votes in favor and 32 against, thanks to the resignation of the monarchists who were the majority in the Assembly [11]. Estanislao Figueras, a federal republican, was elected President of the executive government and the constituent elections scheduled on 10 May 1873, which gave an astonishingly majority of seats for the federal republicans, although in a very low turnout and thanks to the abstention of most of the political factions of the country. Finally, the Democratic Federal Republic was proclaimed by the Constituent Cortes on 7 June 1873, without parliamentary debate or discussion [13].

In the same session, on 7 June 1873, President Estanislao

10 Diary of Sessions of the Spanish Congress since 1808-: http://www.congreso.es/est sesiones/ (16 August 2017).

11 As Amadeo of Savoy abdicated, the Congress of Deputies and the Senate conformed a single National Assembly.
Figueras announced his resignation from the executive government and presented a proposition bill entrusting Pi y Margall -who was then Ministry of Interior or Gobernaciónthe formation of a new executive government for its approval by the Cortes. It is interesting to note that both decisions, the proclamation of the Democratic Federal Republic on 7 June 1873 and the commendation to Pi y Margall to propose a new executive, were considered by several MPs a violation of the parliamentary regulations, insofar as they were put to the vote without parliamentary debate ${ }^{12}$.

In this regard, President Figueras argued that the unity among the republicans implied that the Spanish Federal Republic should be "proclaimed by acclamation without need of discussion". As a result, the proposition bill, consisting of a single article declaring the form of Government of "the Spanish Nation the Democratic Federal Republic", passed "as an urgent procedure" without discussion or debate $[13]^{13 .}$

The above shows the unstable circumstances under which the Democratic Federal Republic was established. Likewise, Pi y Margall was entrusted the formation of a new executive government in an "urgent" move due to the uncertain political environment of the country ${ }^{14}$. Although his commendation passed by nominal voting 142 votes in favor and 58 against $^{15}$ [13], Pi y Margall withdrew his proposal due to the lack of parliamentary consensus. After a private session, the Chamber reelected Figeras' executive [14]. In spite of this earlier withdrawal, Pi y Margall was finally elected President of the executive by the Cortes on 11 June 1873, when Figueras flew to France incapable of dealing with the political instability, and a planned cop ("pronunciamiento") was prepared by general Manuel Sodas [15].

Overall, the Spanish first Republic lasted just eleven months, covering the abdication of King Amadeo of Savoy on 11 February 1873 and the plot orchestrated by General Manuel Pavía, on 3 January 1874, that paved the wat to the "pronunciamiento" of the Spanish officer Arsenio Martínez-Campos y Antón, on 19 Decemeber 1874, that restored the Bourbon monarchical dynasty and gave way to

12 For the parliamentary regulations that were applicable during the "Revolutionary Six Years" period see Merino Merchán [39]. Also see "Dictámen de la commisión de Reglamento para el gobierno interior de las Cortes Constituyentes"' [12].

13 The bill proposal had been submitted by PMs Adolfo de la Rosa, Ángel de Torres, Ramos Pérez Costales, Domingo Sánchez Yago, Manuel Lapizburú, José Ramírez y Duro and Tomás de la Calzada. However, several deputies, among them Alfaro, García Ruiz and Sainz de Rueda, López García, Depute Benot, Sainz de Rueda and Ruiz Llorente, urged the Cortes to proceed according to the parliamentary rules and submit the proposition to debate in the Cortes. Finally, the bill passed by 219 in favor and 2 votes against without parliamentary debate. Only MPs García Ruiz and Rios y Rosas voted against.

14 The proposition was signed by MPs Rafael Cervera, Agustín Sardá, José María Torres, Salustio V. Alvarado, Eduardo Palanca, Joaquín Gil Bergen and Modesto Martínez Pacheco [13].

15 The new executive was made up the following names: Presidency and Ministry of Interior (Gobernación), Pi y Margall; Minister of State, Rafael Cervera; Minister of Justice, Manuel Pedregal; Minister of War, Nicolás Estébanez; Minister of Development (Fomento), Eduardo Palanca; Minister of Finance, José de Carvajal; Minister of Navy, Jacobo Oreiro; Minister of Overseas (Ultramar), José Cristóbal Sorní [14]. 
the historical period known as the Spanish Restoration. In the meantime, during the eleven months of the republican regime, five elections, seven legislatures, two of them constituents, and four Presidents -Estanislao Figueras, Francisco Pi y Margall, Nicolás Salmerón and Emilio Castelar-, succeeded, which testifies to the political turmoil and instability of the regime. The Carlist wars, the economic crisis, attempts at military plot and the cantonal revolts that broke out in several provinces of the peninsula, were major threats that ended with defeat of the republican government. Pi y Margall, then President of the Republic, resigned on July 1873, unable to calm internal divisions and guarantee the necessary order among intransigent federalists and insurgents. Nor did his successors, Salmerón and Castelar, manage to tame internal divisions and contain the cantonal revolutions. Broadly, besides ideological discrepancies, Spain was being cut into multiple parts by cantonalist rebellions and traditionalist Carlists [38, 48, 49].

In spite of all these setbacks, the short republican regime gives insight into the ideas and goals underpinning Spanish nineteenth-century federalism. Moreover, it reflects too wide a gap to be overcome between the high political and moral aspirations of Spanish federalist thinkers such as $\mathrm{Pi}$ y Margall, and the political reality of the country, which was deeply divided. Federalism was allegedly the best way to modernize Spain according to the most progressive values of that time -international pacifism and cosmopolitanism, democratic principles and social reforms benefiting the working classes-, while preserving the historical territorial divisions and prerogatives. Yet, these were in fact too antagonistic goals.

Was such antagonism a theoretical or a practical incompatibility? To the discussion of the federal and republican principles that were enshrined in the constitutional project of 1873 will be devoted the next section. Therein the so-called ontological dualism of federalism is analyzed. To conclude, in section four will be presented an argument in favor of the principle of citizenship.

\subsection{The Debate of Ideas: Spanish Failed Project of a Federal Constitution of 1873 and the Paradoxes of Federalism.}

The first and only explicitly federal system in the democratic history of Spain was the first Republic's. In that country, nineteenth-century federal ideas and principles were embodied in the Project of a Federal Constitution of the Spanish Republic of 1873, which never came into force. The Preamble of the failed constitutional project declared an "authentic liberal, democratic and republican federation" [11], thereby illustrating the commitments of the Spanish federalists.

It is interesting to note that democratic, republican and federal ideals where closely interrelated in late nineteenth-century Spain. A clear example is the denomination of the Spanish Republican Democratic Federal Party ${ }^{16}$ that was formed as a split from the Democratic Party after the "Glorious Revolution" of September 1868. In fact, the Democratic Party, which was created in 1849 , aimed to embrace progressive, democratic, republican, and socialist forces jointly, in an effort to advance the most progressive values and trends of Spanish liberalism. However, internal divisions led to the disintegration of the Party in 1868, in part due to the republicans' disagreement with the unionits that supported Serrano's Government after the Glorious Revolution. As a result, the democrats ended up divided between centralists (unionists) and federalists (for a further discussion on the issue see Peyrou Tubert [45]).

Given such ideological complexity, it is not surprising that the Preamble of the federal Constitution, which was drafted by Emilio Castelar, declared Spain a liberal, democratic, and republican federation. Three main objectives were therein mentioned: Firstly, "the preservation of liberty and democracy that were conquered by the Glorious Revolution"; secondly, "the arrangement of a territorial division that, deriving from historical memories and differences, would ensure a solid Federation, and with it, the national unity"; thirdly, "the division of powers so that, with clear and underlined limitations, would never be mixed nor confused to restrict any right or establish a dictatorship" ${ }^{17}$.

In order to understand more fully the significance of these goals, it can be instructive to read carefully the following paragraph of the constitutional Project:

“(...) We could probably have divided more scientifically the individual rights and could have grouping them with more delicate art; yet, we have sacrificed everything to the idea that we are not breaking foolishly with the past, but have improved it, so that it can be seen that the Republic is linked to the whole liberal movement of our time" (the emphasis has been added $)^{18}$.

It is worth noting that, as can be seen in the foregoing quotation, Spanish federalists were in fact attempting to attain two seemingly contradictory goals: On the one hand, the consolidation of individual rights and civil liberties in tune with the "whole liberal movement of their time", and on the other hand, the resort to history (the "past") to preserve former territorial divisions and prerogatives within the federal pact (foedus). In short, federal republicans wanted to stablish and consolidate modern liberal and democratic principles without "breaking with the past".

What was the meaning of the expression "without

16 Partido Republicano Democrático Federal, also Partido Republicano Federal.

17 The emphasis has been added. I have tried to follow, as far as possible, the original wording of the Spanish [10].

18 The original text in Spanish reads as follows: "quizás hibiéramos podido dividir más científicamente los derechos individuales y agruparlos con más delicado arte; pero lo hemos sacrificado todo a la idea de mostrar que no rompemos desatentadamente con lo pasado, sino que lo mejoramos, para que prácticamente se vea cómo la República se enlaza con todo el movimiento liberal de nuestro tiempo" [10]. 
breaking with the past"? The sentence clearly referred to former territorial divisions and prerogatives of the Spanish kingdoms and regions $[46,47]$. Such prerogatives were in fact pre-modern; they were medieval monarchical privileges -such as the Spanish fueros- which were clearly at odds with modern citizenship egalitarianism. At the end they had decided to "sacrifice" the "scientific division" of the individual rights to "improve the past". But, was this a feasible goal in light of the radicalism of some federalist factions?

Along with modern democratic principles and social egalitarianism, Pi y Margall advocated the ontological existence of local and regional communities based on historical divisions and prerogatives, what he called "the nationalities principle" [46]. Indeed, a key goal and principle of federal republicans was the balance between unity and diversity. Pi y Margall was inspired by empirical experiences such as the Swiss federation and the United States, and was well acquainted with Proudhon's Du principe Fédératif ${ }^{19}$. The latter essay contained, in fact, similar dualism and raised the same kind of political paradox [51]. The republican federation was, according to the Spanish federal thinker, the suitable solution to the territorial, economic and political problems afflicting Spain since the Catholic Kings, which he mainly attributed to the administrative centralization (unitarism), which had led to economic inefficiency, and to the corruption of the monarchy $[36,46,47]$. His own words may result illustrative: "The events show us once again that we need to change the system and adopt a principle which, in its own virtuosity, reconstructs the very last municipality up to Europe. This principle is in my view, the federation is the only one that can gather, in an organic whole, our whole lineage" $[46]^{20}$.

The federal constitutional project of 1873 arranged the decentralization of the State in Titles I and III "according to the principles of liberty and the State of Law" (Preamble) ${ }^{21}$. The ideal situation was, according to Pi y Margall, to enhance a bottom-up process of federation starting from the provinces (juntas) and the states (cantons) to the federal pact (foedus) to reach national unity, and even a larger European cosmopolitan federation $[46,53,54]$. However, in practice, when the cantonal revolts were threatening to jeopardize the first Republic from 1873 to 1874 , the then President of the Republic stood on behalf of the national unity and the

19 The Spanish politician and thinker was, indeed, the main translator of Pierre-Joseph Proudhon's works into Spanish. However, along with Proudhon's ideas, Pi y Margall's federalism linked with cosmopolitan and pacifist movements leadered by figures such as Victor Hugo, Giuseppe Mazzini and Carlo Cattaneo [36]

20 The original text reads as follows: "Demuestran los sucesos una vez más que necesitamos cambiar de sistema y adoptar un principio que, por su propia virtualidad, reconstituya sin esfuerzo desde el último municipio hasta la misma Europa. Este principio es para mí el de la federación, el único que puede reunir en un todo orgánico nuestro linaje" [46].

21 The constitutional project of 1873 was made of 117 articles, distributed into 18 titles. It defined Spain as a federal republic integrated by the following states: High Andalusia, Low Andalusia, Aragón, Asturias, Baleares, Canarias, Castilla the New, Castilla the Old, Catalonia, Cuba, Extremadura, Galicia, Murcia, Navarra, Puerto Rico, Valencia and Basque Regions.
Constituent Cortes to counteract the revolts in several provinces [46, 47]. This was viewed by some radical republican sectors as a betrayal to their federal principles by the central Government [36]. At the end, Pi y Margall had to support the gradual decentralization supervised by the Cortes against his own theories and political allies.

There were, of course, other important issues on the agenda of the Spanish federalists. For example, social and economic reforms, the working class, and the abolition of quintas, that is, the mandatory military service that only the wealthier could avoid $[36,63]$. Broadly, in the second half of the nineteenth century, the federation was considered, by its republican ideologists, the best way of enhancing and completing the country's democratization -by means of universal suffrage and socio-economic reforms-, and fostering its modernization -by guaranteeing the freedoms of thought, religion and education "in contrast to the restricted individual rights that were enshrined by the moderate regime" (of Isabel II)- [36, 46, 63].

Ideally, the federal principle would achieve a balance between the improvement of citizenship rights and the arrangement of the territorial decentralization according to historical prerogatives and traditions. Finally, a broader international European federation among free republics would be gradually encouraged. The reality was, however, that cantonal rebels and traditionalist insurgents alike were incapable of showing loyalty to Spain as their common patria. Without internal unity, Spanish federal republicans were unable to defeat the monarchical opposition.

In my view, along with these internal divisions and civil wars, Spanish nineteenth-century federalism raised a main paradox: the federalists, like Pi y Margall and Castelar, appealed to pre-modern history and territorial divisions to foster the decentralization of power, while, at the same time, they advocated the modernization of Spain according to liberal principles and citizenship rights. In this regard, their theory combined two apparently contradictory political ontologies: On the one hand, the territorial divisions and prerogatives that were, in fact, pre-modern and medieval (what they called "the past"), and, on the other hand, liberal citizenship and modern democratic values. The extent to which these two different and even antagonist political ontologies can be combined is a matter of reflection and debate.

\section{Concluding Remarks: Citizenship and Federalism}

Federalism is based on the creation of a political community by pact or covenant (foedus). It is in this regard that federalism fulfils a basic requisite of modern political thought in tune with the civil pact of citizenship [17, 52].

However, Citizenship is basically a political and civil creation [38]. By contrast, the idea of the federation (foedus) admits the ontological existence of nations and states which 
are prior to the political covenant that creates the federal polity.

As has been pointed out by Ernest Gellner, the principle of nationalism is based on the paradoxical doctrine holding that when a given ethnic community claims its political autonomy it is precisely because its members feel that they belong to a cultural community or a nation; that is, the claims of political autonomy and self-government are justified on the bases of sentiments and identities that are prior to the political covenant or constitution [22]. By contrast, citizenship consists of a common basic civic status shared by the members of a political community. It is this common civic status that allows the extension of rights - from civil to social and political and so on- [38]. The civic and political status of citizenship basically differs from cultural and ethnic belongings in that the latter's bonds are based on allegiances and identities that are not necessarily civic, that is, that can be prior to the civil and political covenant and constitution. For this reason, Spanish nineteenth-century federalism seemed to combine two apparently antagonistic ontologies: civic and cultural.

Indeed, this is the case of the federal systems that hold multi-level political belongings on basis of cultural identities and divisions.

Moreover, in the EU, unity and diversity happen to be the two basic principles that capture the double dimension of the European polity. On the one hand, the EU encompasses an inter-governmental and inter-state decision-making structure (represented by the Council and the European Council), and, on the other hand, it has given place to a supranational citizenship represented by the democratically elected European Parliament. Hence, the EU combines the principle of citizenship -a dual form of citizenship, national and supranational- and the principle of interstate or intergovernmental decision-making, supported by a multi-level legal and constitutional system [19,20,40,48-50,64].

It is important to note, however, that the $\mathrm{EU}$ is the outcome of decades of tough diplomatic negotiations and cooperation among sovereign states aiming at advancing their common interests. The extent to which EU citizenship is to flourish counteracting European inter-governmentalism will be a decisive factor in EU's future. With regard to federalism, it is also to be seen whether it will yield to the demands of a cosmopolitan citizenship or to the nationalist principle and ontology.

\section{Acknowledgements}

This paper is part of the outcomes of the Research Project Civic Constellation (CivCons) II: Debating Democracy and Rights (Spain's National Research Fund, I+D+i, FFI2014-52703-P, 2015-2018)

https://www.uma.es/civicconstellation/cms/menu/project/pr esentation/. I am grateful to the coordinators of the Project,
José María Rosales and Manuel Toscano, and its members for their encouragement and insightful comments.

Some of the ideas herein presented have previously been discussed at the following conferences and workshops: Panel 2: Exploring the Parliamentary and Democratic Languages of Politics, IPSA's 24th World Congress (Poznan, Poland, 23-28 September 2016); Workshop 6: "Methodology and Interdisciplinarity in Political Philosophy", Spanish Association of Ethics and Political Philosophy's (AEEFP) "XVIII Semana de Ética y Filosofía Política. Desafíos públicos" (University of Córdoba, Spain, 13-15 January 2016); Workshop I, "Debating Democracy and Rights: Methodological and Thematic Issues", Civic Constellation II, University of Málaga, 18-19 December 2015.

\section{REFERENCES}

[1] Ayzagar, Javier y Gonzalo Capellán de Miguel, Federalismo, Diccionario politico y social del siglo XIX español, Javier Fernández Sebastián y Juan Francisco Fuentes (dirs.), Alianza Editorial, Madrid, 2002, 305-310.

[2] Beck, Ulrich, What is Globalization?, Polity Press, Cambridge, 1999.

[3] Beck, Ulrich, Risk Society. Towards a New Modernity, Sage, London, 1992.

[4] Beck, Ulrich, The Cosmopolitan Perspective: Sociology of the Second Age Modernity, British Journal of Sociology, Vol. 51 (January-March, 2000), 79-105.

[5] Beck, Ulrich, Cosmopolitan Vision, Polity Press, Cambridge, 2006.

[6] Beck, Ulrich y Edgar Grande, Cosmopolitan Europe, Polity Press, Cambridge, 2007.

[7] Burgess, Michael, Federalism and the European Union: The Building of Europe, 1950-2000, Routledge, London, 2000.

[8] Castaldi, R., A Federalist Framework Theory on European Integration", Centro Studi Federalismo, 2007, 1-93.

[9] Castells, Manuel, The Rise of the Network Society. The Information Age: Economy, Society and Culture. Vol. I. Oxford, Blackwell, 1997.

[10] Diary of Parliamentary Sessions of the Spanish Republic, 2nd Appendix No. 42 (17 July 1873): Proyecto de Constitutución Federal de la República Española (online: http://www.congreso.es/docu/PHist/docs/04sexe/ds1873proye cto_constitucion.pdf).

[11] Diary of Parliamentary Sessions of the National Assembly of 1873, Num. 1, 10 February (official web of the Spanish Congress: http://www.congreso.es/est_sesiones/, 22 July 2016).

[12] Diary of Sessions of the Constituent Cortes of the Spanish Republic of 1873, "Dictámen de la commisión de Reglamento para el gobierno interior de las Cortes Constituyentes", Appendix to Num. 4, 4 June, http://www.congreso.es/est_sesiones/. 
[13] Diary of Sessions of the Constituent Cortes of the Spanish Republic of 1873, Num. 8, 7 June,

http://www.congreso.es/est_sesiones/.

[14] Diary of Sessions of the Constituent Cortes of the Spanish Republic of 1873, Num. 9, 8 June,

http://www.congreso.es/est_sesiones/.

[15] Diary of Sessions of the Constituent Cortes of the Spanish Republic of 1873, Num. 12, 11 June,

http://www.congreso.es/est_sesiones.

[16] Dosenrode, S. Federalism Theory and Neo-Functionalism: Elements for an Analytical Framework, Perspectives on Federalism, Vol. 2, Issue 3 (2010), 1-28.

[17] Elazar, Daniel J., The Covenant Idea and the Jewish Political Tradition. Ramat Gan: Bar Ilan University, Department of Political Studies and Center for Jewish Community Studies, 1983.

[18] Elazar, Daniel J., Exploring Federalism, The University of Alabama Press, Tuscaloosa and London, 1987.

[19] Fabbrini, M., Transatlantic Constitutionalism: Comparing the United States and the European Union, European Journal of Political Research, 43 (2014), 547-569.

[20] Fabbrini, M., The European Multilevel System for the Protection of Fundamental Rights: A "Neo-Federalist Perspective", Jean Monnet Working Paper, 15/10 (2010).

[21] Friedman, Thomas L., The World is Flat. A Brief History of the Twenty-First Century, Picador/ Farrar, Straus and Giroux, New York, 2005.

[22] Gellner, Ernest, Nations and Nationalism, Cornell University Press, Ithaca, 1983.

[23] Guibernau, Montserrat, Prospects for an Independent Catalonia, International Journal of Politics, Culture, and Society, Vol. 27, No. 1 (2014), 5-23.

[24] Habermas, Jürgen, The Postnational Constellation, Polity Press, Cambridge, 2001.

[25] Hamilton, Alexander, John Jay and James Madison, The Federalist Papers [1788], The Project Gutenberg E-Book, online.

https://www.gutenberg.org/files/1404/1404-h/1404-h.htm (8 August 2017).

[26] Held, David, Democracy and the global order. From the Modern State to cosmopolitan governance, Polity Press, Cambridge, 1995.

[27] Held, David y Anthony McGrew, Globalization/anti-globalization, Polity Press, Cambridge, 2002.

[28] Hobsbawn, Eric, Globalization, Democracy and Terrorism, Little Brown, London, 2007.

[29] Hueglin, Thomas O., Early Modern Concepts for a Late Modern World. Althusius on Community and Federalism, Wilfrid Laurier University Press, Waterloo, 1999.

[30] Jewkes, Michael, Diversity, Federalism and the Ninetheenth-Century Liberals, Critical Review of International Social and Political Philosophy, Vol. 19, Issue. 2 (2016), 184-205. http://www.tandfonline.com/doi/full/10.1080/13698230.2014 .978639

[31] Koselleck, Reinhart, Social History and Conceptual History, The Practice of Conceptual History: Timing History, Spacing Concepts, Stanford University Press, Stanford, 2002.

[32] Koselleck, Reinhart, Begriffsgeschichten. Studien zur Semantik und Pragmatik der politischen und sozialen Sprache, Suhrkamp, Frankfurt, 2006.

[33] Koselleck, Reinhart, Introduction (Einleitung) to the Geschichtliche Grundbegriffe, Contributions to the History of Concepts, 6/1 (2011), 7-25

[34] Kymlicka, Will, Multicultural Citizenship. A Theory of Minority Rights, Clarendon Press, Oxford, 1995

[35] Kymlicka, Will, Is Federalism a Viable Alternative to Secession? In Percy B. Lehning, dir. Theories of Secession, Routledge, London and New York, 1998, 111-150.

[36] López-Cordón, María Victoria, El pensamiento político-internacional del federalismo español (1868-1874), Planeta, Barcelona, 1975.

[37] López, Rosario and José María Rosales, eds. Interdisciplinarity and Methodological Pluralism: The Practice of Intellectual History and Conceptual History, Special Issue of Global Intellectual History (Forthcoming).

[38] Marshall, T. H., Citizenship and Social Class, Cambridge University Press, 1950.

[39] Merino Merchán, José Fernando, Los reglamentos parlamentarios durante el Sexenio Revolucionario, Revista de Derecho Político, No 55/56 (2002), 295-342.

[40] Neergaard, Ulla and Ruth Nielsen, eds., European Legal Method - in a Multi-Level EU Legal Order, DJØF Publishing, Copenhagen 2012.

[41] Palonen, Kari, Rhetorical and Temporal Perspectives on Conceptual Change: Theses on Quentin Skinner and Reinhart Koselleck, Finnish Yearbook of Political Thought, 3 (1999), 141-159.

[42] Palonen, Kari, Tuija Pulkkinen and José María Rosales, eds., The Ashgate Research Companion to the Politics of Democratization in Europe: Concepts and Histories, Ashgate, Farnham, 2008.

[43] Palonen, Kari, Politics and Conceptual Histories. Rhetorical and Temporal Perspectives, Nomos Verlagsgesellschaft, Baden-Baden, 2014.

[44] Pasture, Patrick, Imagining European Unity since 1000 AD, Palgrave MacMillan, New York, 2015.

[45] Peyrou Tubert, Florencia, La formación del Partido Demócrata español: ¿Crónica de un conflicto anunciado?, Historia Contemporánea 37 (2008), 343-372.

[46] Pi y Margall, Francisco, Las nacionalidades, Librería Bergua, Madrid, [1876] 1936.

[47] Pi y Margall, Francisco, El reinado de Amadeo de Saboya y la República de 1873, Seminarios y Ediciones S. A., Madrid, 1970 
[48] Postigo, Marta, A Political-Philosophical Analysis of the EU Legal Order and European Integration: Federal and Cosmopolitan Perspectives, European Legal Method Towards a New European Legal Realism? Ulla Neegard and Ruth Nielsen, eds. DJØF Publishing, Copenhagen, 37-55, 2013 .

[49] Postigo, Marta, Beyond the Nation-State: The European Union and Supranational Democracy, Varieties of Liberalism. Contemporary Challenges. Jan Harald Alnes and Manuel Toscano, eds., Cambridge Scholars Publishing, Newcastle upon Tyne, 2014, 172-190.

[50] Postigo, Marta, The European Union as a Cosmopolitan Civic Space: Conceptual Backgrounds and Contemporary Challenges, Ideas and Realities of Democracy: Meeting the Challenges of Contemporary Citizenship, Marta Postigo and Rosario López, coords., Contrastes. Revista Internacional de Filosofía, Special Issue (Supplement) 20 (2015), 201-220.

[51] Proudhon, Pierre-Joseph, El principio federativo, El Cird Editor, Córdoba, [1863] 2004.

[52] Riley, Patrick, Rousseau as a Theorist of National and International Federalism, Publius 3, No 1 (20173), 5-18.

[53] Rivera García, Antonio, La idea federal en Pi y Margall, Arancaria, No 4 (2000), 113-141.

[54] Rivera García, Antonio, Federalismo y derecho cosmopolita en el marco de la crisis global de la soberanía, Daimon. Revista de Filosofía, No 29 (2003), 155-170.

[55] Rius-Ulldemolins, Joaquín and Mariano M. Zamorano, Federalism, Cultural Policies, and Identity Pluralism: Cooperation and Conflict in the Spanish Quasi-Federal System, Publius: The Journal of Federalism, Vol. 45, No 2 (2015), 167-188.

[56] Rosales, José María and Manuel Toscano, eds., Rhetoric, Ethics and Democracy, Res Publica: Revista de Filosofía Política, Issue 27 (2012), 3-165.

[57] Rosales, José María, ed., Concept in Focus: Liberalism's Historical Diversity, Contributions to the History of Concepts, 8:2 (2013), 67-118.

[58] Schmitter, Philippe, How to Democratize the European Union
- and Why Bother? Rowman \&Littlefield Publishers, Inc., Lanham, 2000.

[59] Schmitter, Philippe, What is There to Legitimize in the European Union....and How Might this be Accomplished, European University Institute (January 2001), online paper, http://www.eui.eu/Documents/DepartmentsCentres/SPS/Profi les/Schmitter/LegitimizeEU.pdf (accessed 15 August 2017).

[60] Skinner, Quentin, Meaning and Understanding in the History of Ideas, History and Theory, 8/1(1969), 3-53.

[61] [61] Stone Sweet, A., The European Court of Justice and the Judicialization of EU Governance, Living Reviews in European Governance, Vol. 5, No. 2 (2010), online edition: $\mathrm{http}: / /$ europeangovernance.livingreviews.org/Articles/lreg-20 $10-2 /$.

[62] Stone Sweet, A., A Cosmopolitan Legal Order: Constitutional Pluralism and Rights Adjudication in Europe, Global Constitutionalism, Vol. 1, No 1 (2012), 53-90.

[63] Trías, Juan J., Federalismo y revolución burguesa, en Federalismo y reforma social en España, Juan J. Trías y Antonio Elorza, Seminarios y Ediciones S.A., Madrid, 1975.

[64] Tuori, Carlo, The Relationality of European Constitution(s). Justifying a New Research Programme for European Constitutional Scholarship, in European Legal Method Towards a New European Legal Realism? Ulla Neegard and Ruth Nielsen, eds., DJØF Publishing, Copenhagen, 2013, 23-37.

[65] Watts, Ronald L., Introduction: Federalism in an Era of Globalization, International Social Science Journal, Vol. 53, Issue 167 (March 2001), 9-12.

[66] Watts, Ronald L., Historical Development of Comparative Federal Studies, Working Paper 1, Queen's University, Kingston, 2007, 1-33.

http://www.queensu.ca/iigr/sites/webpublish.queensu.ca.iigr www/files/files/WorkingPapers/Archive/2007/wattsIPSA200 7.pdf (30 August 2017).

[67] Weinstock, D., Towards a Normative Theory of Federalism, International Social Science Journal, Vol. 53, Issue 167 (2001), $75-83$. 